\title{
Desain Trash Skimmer Amphibi-Boat di Sungai Ciliwung Jakarta
}

\author{
Nurin Farras Adiba dan Hesty Anita Kurniawati \\ Jurusan Teknik Perkapalan, Fakultas Teknologi Kelautan, Institut Teknologi Sepuluh Nopember (ITS) \\ Jl. Arief Rahman Hakim, Surabaya 60111 Indonesia \\ email: tita@na.its.ac.id
}

\begin{abstract}
Abstrak-Jakarta sebagai Ibu Kota Indonesia memiliki masalah yang cukup serius yaitu banjir setiap tahun yang disebabkan timbunan sampah khususnya di sungai-sungai. Penelitian ini mempunyai tujuan untuk melakukan analisis secara teknis mengenai desain kapal amfibi dengan jenis lambung katamaran yang digunakan untuk mengangkut sampah dengan conveyor di bagian haluan dan buritan kapal. Pemilihan kapal katamaran dikarenakan katamaran memliki geladak yang luas sehingga dapat mengangkut muatan lebih banyak. Selain itu kapal katamaran dapat digunakan di perairan yang cukup dangkal sehingga cocok untuk kondisi Sungai Ciliwung. Proses desain kapal dilakukan dengan menggunakan satu kapal sebagai kapal acuan dalam menentukan ukuran utama dengan data jumlah sampah yang ada di Sungai Ciliwung digunakan sebagai acuan dalam penentuan payload. Perhitungan teknis lainnya menggunakan rules untuk kapal katamaran dengan $\mathrm{L}<50 \mathrm{~m}$. Hasil perhitungan teknis diperoleh ukuran utama sebesar $L p p=10.6 \mathrm{~m}$, $\mathrm{B}=4 \mathrm{~m}, \mathrm{~T}=1 \mathrm{~m}, \mathrm{H}=2 \mathrm{~m}, \mathrm{~B}_{1}=1.2 \mathrm{~m}, \mathrm{C}_{B}=0.579$, dan Vs $=4$ knots. Selanjutnya dari ukuran utama yang diperoleh dibuat Gambar Rencana Garis dan Gambar Rencana Umum. Terdapat roda yang terpasang pada sisi luar lambung kapal sehingga kapal amfibi dapat dioperasikan di sungai dan daratan. Pengoperasian di daratan sebatas untuk proses berpindahnya kapal amfibi ke sungai lain. Selain di Sungai Ciliwung, kapal ini dapat dioperasikan di Sungai Sunter dan Sungai Banjir Kanal Timur.
\end{abstract}

Kata kunci - amphibi vessel, conveyor, katamaran, Sungai Ciliwung, trash skimmer.

\section{PENDAHULUAN}

$\mathbf{J}_{\mathrm{p}}^{\mathrm{A}}$ AKARTA memiliki luas sekitar $661,52 \mathrm{~km}^{2}$ dengan jumlah penduduk 10.187.595 jiwa. Dengan data luas wilayah dan jumlah penduduk yang ada, tidak heran jika Jakarta menjadi kota terpadat di Indonesia. Jumlah penduduk yang tinggi otomatis menyebabkan tingkat produktifitas sampah yang tinggi setiap harinya. Pengelolaan dan penanganan sampah yang kurang benar menimbulkan munculnya timbunan sampah di beberapa lokasi salah satunya di perairan sungai. Timbunan sampah di sepanjang aliran sungai mengakibatkan dampak negatif bagi warga sekitar sungai salah satunya dapat menyebabkan badan sungai tertutupi oleh sampah yang pada akhirnya menyebabkan air sungai meluap jika terjadi hujan yang cukup deras. Banjir pun tidak dapat dihindari.

Di Jakarta terdapat 14 sungai besar yang mengalir di tengah kota antara lain Sungai Cipinang, Sungai Ciliwung, dan Sungai Sunter. Hampir semua sungai tersebut tidak luput dari adanya sampah di aliran sungai, namun timbunan sampah yang paling banyak terjadi di Sungai Ciliwung. Berdasarkan data jumlah sampah yang ada di aliran sungai di Jakarta, tak dapat dihindari jika hampir setiap musim hujan datang, kota metropolitan nomer satu di Indonesia tersebut dilanda banjir. Hingga tahun 2014 Pemerintah Jakarta belum dapat mengatasi malasah paling utama kota tersebut.

Oleh karena itu pada Tugas Akhir ini dilakukan perencanaan desain kapal kerja pembersih sampah yang sesuai dengan karakteristik Sungai Ciliwung. Selain itu pada penelitian ini dilakukan analisis tentang penggunaan roda pada kapal sehingga kapal dapat pula beroperasi di darat. Hal tersebut bertujuan agar kapal dapat digunakan di sungai lain yang memiliki karakteristik dan jenis sampah yang sama dengan Sungai Ciliwung.

\section{TINJAUAN PUSTAKA}

\section{A. Sungai Ciliwung Jakarta}

Sungai Ciliwung merupakan sungai di Tatar Pasundan yang melewati wilayah ibukota DKI Jakarta. Sungai ini memiliki panjang hampir $120 \mathrm{~km}$ dengan luas daerah aliran sungai 387 $\mathrm{km}^{2}$. Sungai Ciliwung memasuki wilayah Jakarta melalui Jakarta Selatan tepatnya di sebelah timur Wilayah Jakarta Selatan. Berkenaan dengan hal tersebut Sungai Ciliwung juga memiliki peran sebagai batas alami antara Jakarta Selatan dan Jakarta Timur [1].

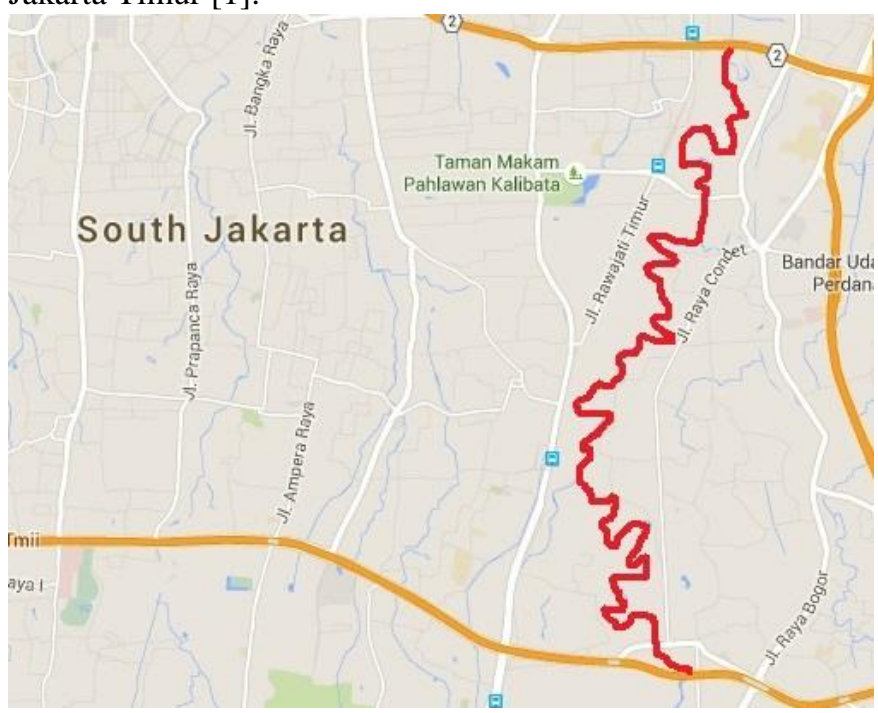

Gambar. 1. Aliran Sungai Ciliwung di Wilayah Jakarta Selatan

Penulis memutuskan untuk mengambil aliran Sungai Ciliwung daerah Jakarta bagian Selatan sebagai daerah rute pelayaran dari kapal kerja yang akan di desain. Gambar 1 
merupakan peta Sungai Ciliwung yang melewati Jakarta bagian Selatan

\section{B. Trash Skimmer Boat}

Trash Skimmer Workboat merupakan kapal kerja jenis pontoon dengan double hull atau dapat biasa disebut catamaran.

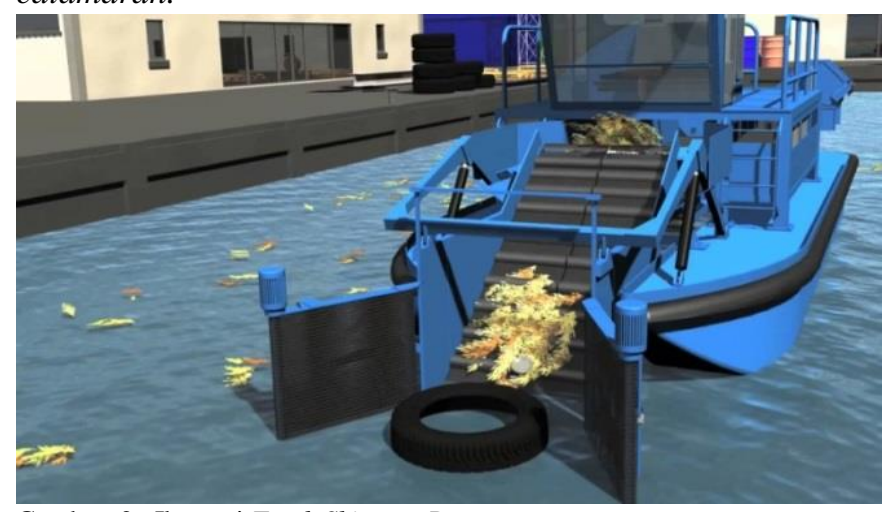

Gambar. 2. Ilustrasi Trash Skimmer Boat

Kapal jenis ini dilengkapi conveyor belt yang dapat dinaikkan dan diturunkan sesuai kebutuhan. Conveyor belt tersebut mempunyai fungsi untuk mengumpulkan sampah yang mengapung di permukaan air sungai dan bak penampung yang berfungsi untuk menampung sampah yang telah dikumpulkan. Pengumpulan sampah dilakukan melalui sisi haluan kapal. Pada sisi haluan kapal yang berfungsi sebagai pintu masuknya sampah terdapat lengan yang dapat digerakkan sesuai keinginan (dibuka atau ditutup). Lengan tersebut digerakkan dengan sistem hidrolik [2].

\section{Kendaraan Amfibi}

Kendaraan amfibi di sini adalah kendaraan yang dapat beroerasi di dua alam, khususnya darat dan perairan. Semakin berkembangnya teknologi memungkinkan bagi peneliti untuk menemukan inovasi, salah satunya adalah kendaraan amfibi.

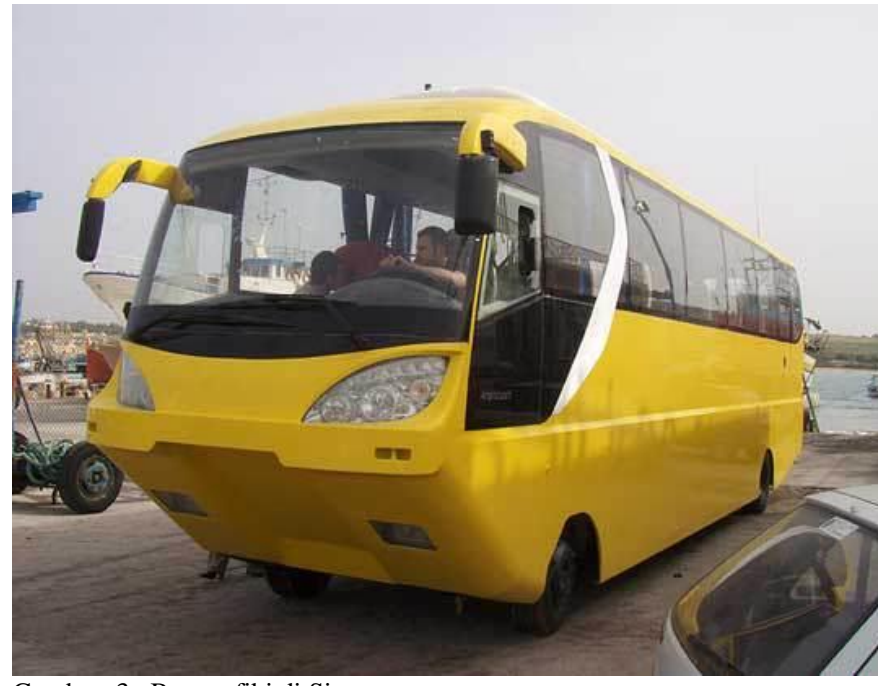

Gambar. 3. Bus amfibi di Singapura

Pada awalnya kendaraan amfibi digunakan untuk keperluan militer yaitu kapal perang, dan tank. Namun saat ini pengaplikasian kendaraan jenis ini sudah cukup banyak digunakan pada kendaraan komersial, khususnya di benua Eropa dan Amerika.

\section{Pendekatan Desain}

Dalam proses mendesain kapal, digunakan pula teknik berulang yang prosesnya terangkum dalam sebuah alur melingkar yang disebut Spiral Design. Proses berulang ini bertujuan untuk menghasilkan sebuah output desain yang maksimal dan sesuai keinginan. Didalam diagram spiral design terdapat 4 pembagian proses yaitu concept design,preliminary design, contract design, dan detail design [3].

\section{E. Kapal Katamaran}

Katamaran merupakan kapal yang mempunyai dua lambung atau badan yang dihubungkan oleh geladak atau bridging platform ditengahnya. Keuntungan kapal katamaran dibandingkan dengan monohull adalah dengan tenaga dorong yang sama kecepatan yang dihasilkan lebih besar, geladak kapal lebih luas, memiliki stabilitas yang lebih baik, lebih nyaman karena sudut oleh lebih kecil. Namun terdapat beberapa kekurang antara lain teori tentang perhitungan masih kurang, pembuatan kapal lebih rumit, kemampuan manuver kurang baik [4].

\section{METODOLOGI PENELITIAN}

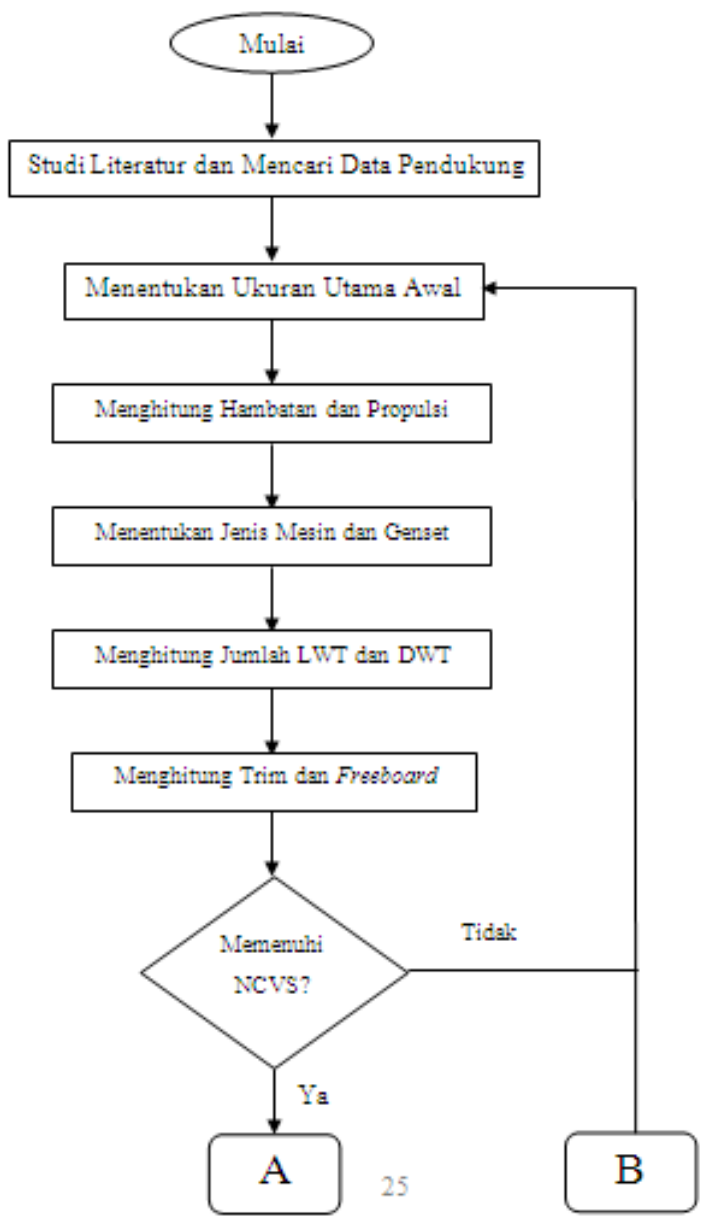

Gambar. 4. Diagram blok penelitian (bagian 1) 


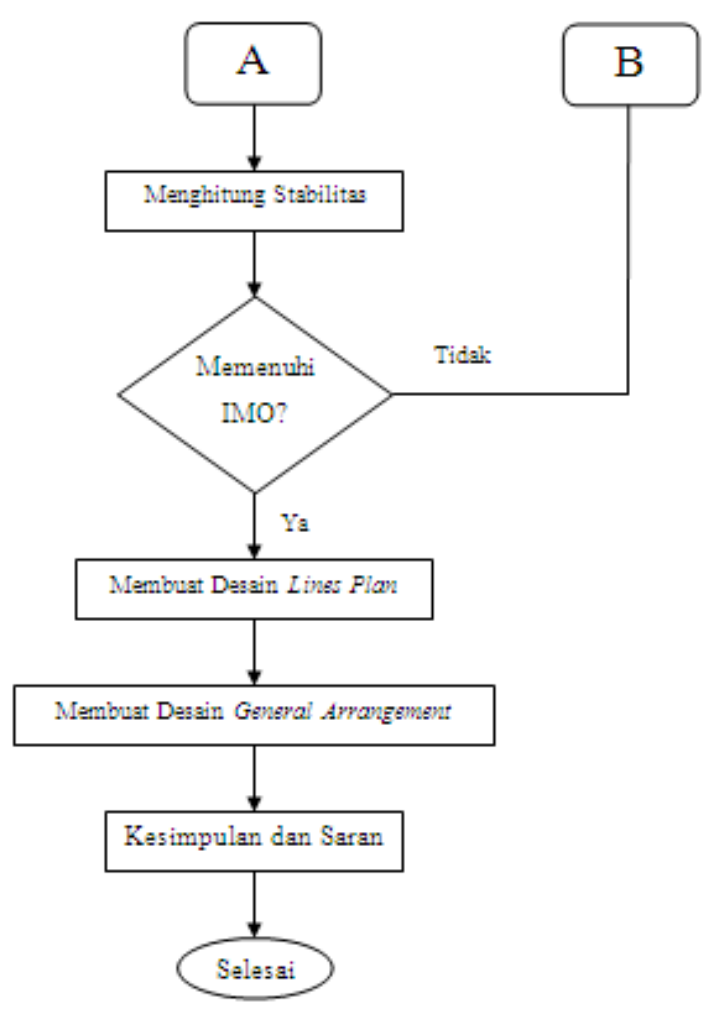

Gambar. 5. Diagram blok penelitian (bagian 2)

\section{ANALISIS TEKNIS}

\section{A. Penentuan Payload}

Saat ini Sungai Ciliwung mengalami kerusakan yang cukup parah jika dibandingkan sungai lainnya yang mengalir di Jakarta. Selain karena daya tampung di bagian hulu di wilayah Puncak dan Bogor yang rusak, badan sungai di wilayah Jakarta juga banyak mengalami penyempitan dan pendangkalan yang mengakibatkan daya tampung air sungai berkurang, dan mudah menimbulkan banjir. Penyempitan dan pendangkalan yang terjadi pada Sungai disebabkan oleh adanya sampah di badan sungai. Pada Tabel 1 dapat dilihat jumlah sampah yang terdapat pada badan Sungai Ciliwung di wilayah Jakarta Selatan pada tahun 2015.

Tabel 1.

Data Jumlah Sampah per Hari di Sungai Ciliwung Wilayah Jakarta Selatan Tahun 2015

\begin{tabular}{ccc}
\hline \hline No. & Bulan & Jumlah Sampah (Ton) \\
\hline 1 & Januari & 37.21 \\
2 & Februari & 37.91 \\
3 & Maret & 38.53 \\
4 & April & 38.62 \\
5 & Mei & 38.42 \\
6 & Juni & 37.76 \\
7 & Juli & 38.02 \\
8 & Agustus & 38.41 \\
9 & September & 37.93 \\
10 & Oktober & 37.85 \\
11 & November & 37.79 \\
12 & Desember & 37.11 \\
\hline \hline
\end{tabular}

Kemudian dilakukan analisis regresi linier untuk menentukan jumlah sampah pada tahun 2016, nilai rata-rata sampah pada tahun 2016 dijadikan sebagai jumlah sampah yang harus diangkut kapal setiap harinya yaitu sebesar 38.046 ton. Berdasarkan kapal acuan dan batasan kedalaman sungai diperoleh besarnya muatan kapal yaitu 5.442 ton dengan 4 kali beroperasi setiap harinya. Jumlah kapal yang dibutuhkan sebanyak 2 buah kapal yang beroperasi selama 1.5 jam setiap satu kali beroperasi.

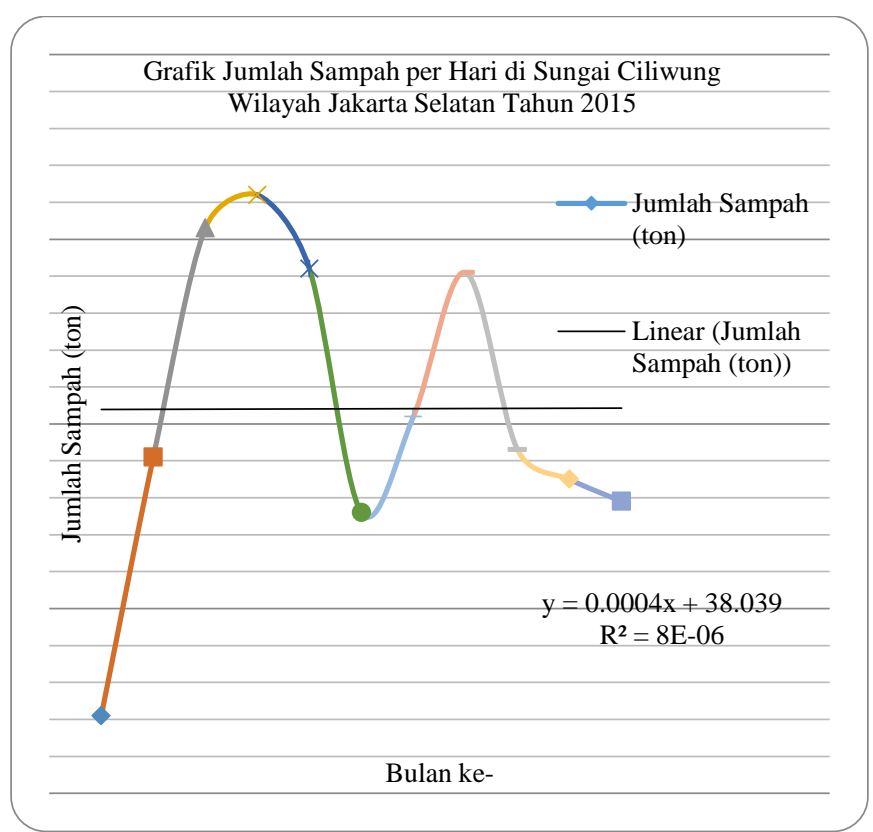

Gambar. 6. Grafik Jumlah Sampah per Hari di Sungai Ciliwung Wilayah Jakarta Selatan Tahun 2015

\section{B. Penentuan Payload}

Dalam menentukan ukuran utama awal, data kapal Marine Skimmer Model \#MS16-12000B digunakan sebagai acuan. Penggunaan data acuan yang hanya berjumlah satu dikarenakan data kapal pembanding yang ditemukan sebanyak dua buah dan merupakan sister ship. Sehingga data kapal yang didapatkan digunakan sebagai acuan, tidak menggunakan analisa regresi linier dalam menentukan ukuran utama kapal. Ukuran utama yang diperoleh dapat dilihat pada Tabel 2 .

Tabel 2.

Ukuran utama kapal

\begin{tabular}{ccc}
\hline \hline Variabel & Value & Unit \\
\hline $\mathrm{L}$ & 10.7 & $\mathrm{~m}$ \\
$\mathrm{~B}$ & 4 & $\mathrm{~m}$ \\
$\mathrm{H}$ & 2 & $\mathrm{~m}$ \\
$\mathrm{~T}$ & 1 & $\mathrm{~m}$ \\
\hline \hline
\end{tabular}

\section{Pembuatan Layout Awal}

Pembuatan layout awal bertujuan untuk mengetahui apakah ukuran utama yang telah didapat dari proses sebelumnya dapat menampung jumlah payload. Layout awal kapal dapat dilihat seperti Gambar 4 di bawah ini. 


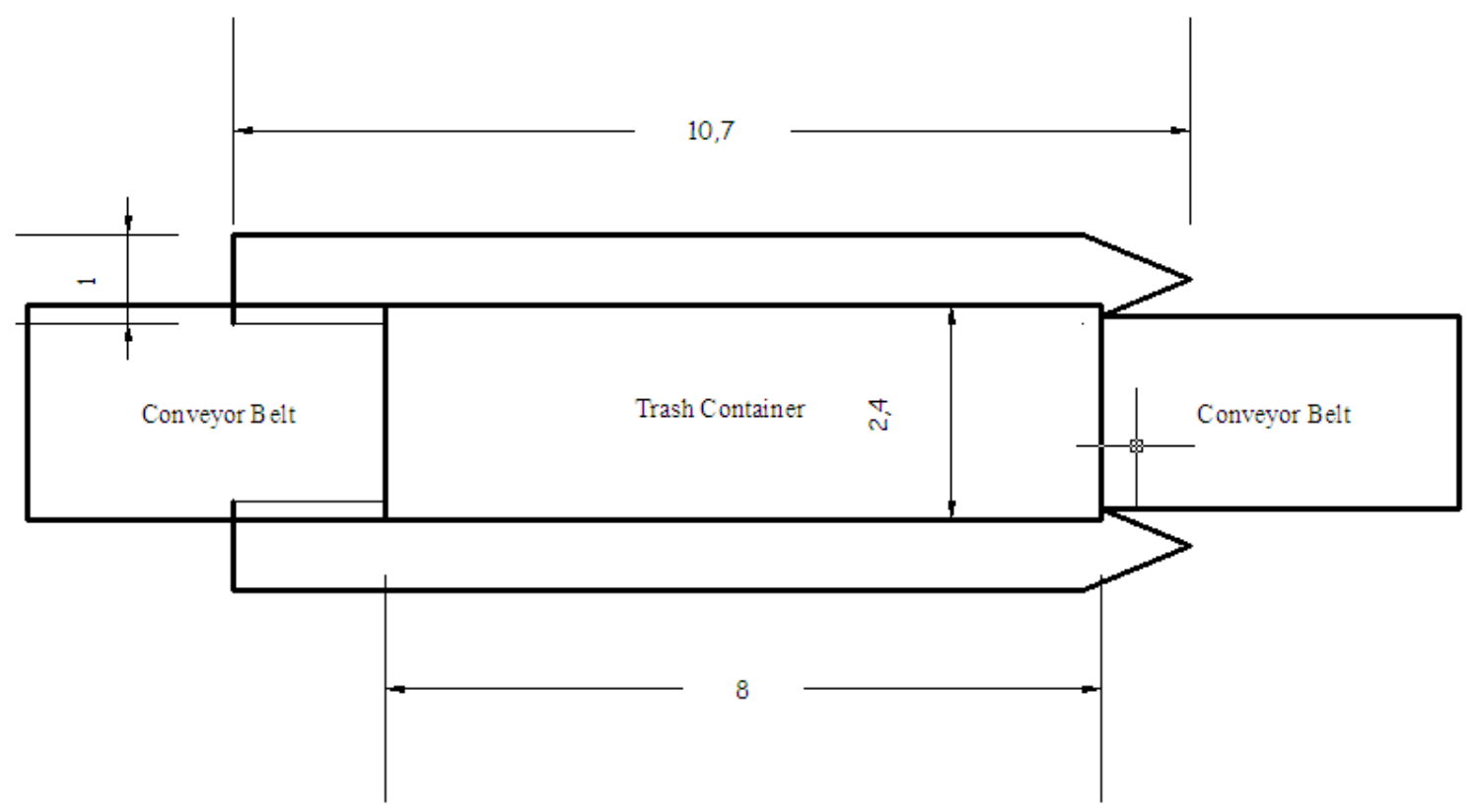

Gambar. 7. Layout awal Trash Skimmer Amphibi-Boat

\section{Perhitungan Teknis}

Komponen perhitungan teknis yang dihitung adalah sebagai berikut:

1) Hambatan

Kapal yang didesain merupakan kapal katamaran multihull dengan demihull terisolasi sehingga untuk perhitungan hambatan menggunakan paper M. Insel dan A.f. Molland sebagai referensi. Setelah diperoleh harga setiap variable maka nilai hambatan total diperoleh sebesar $702.754 \mathrm{~N}$.

2) Daya Kapal

Perhitungan daya kapal dilakukan untuk mengetahui besarnya daya yang dibutuhkan agar kapal dapat beroperasi sesuai dengan kecepatan yang diinginkan. Berdasarkan perhitungan diperoleh nilai daya kapal (BHP) sebesar 3.775 $\mathrm{kW}$.

3) Pemilihan Mesin Induk

Pada dasarnya pemilihan mesin induk mengacu pada perhitungan BHP mesin. Namun karena kapal amfibi, dalam pemilihan mesin perlu dipertimbangkan adanya roda sebagai sistem gerak kapal. Oleh karena itu digunakan kendaraan darat dengan berat mendekati berat kapal dalam menentukan mesin dan roda yang dipakai. Kendaraan yang dijadikan sebagai acuan adalah Truk ISUZU Model FRR 90 Q - 190 PS dengan daya mesin sebesar 190 PS atau $140.6 \mathrm{~kW}$. Karena jumlah daya untuk mesin truk lebih besar dibandingkan daya hasil perhitungan, maka daya yang digunakan untuk pemilihan mesin adalah daya mesin truk. Berdasarkan daya yang dibutuhkan maka dipilih mesin Yanmar dengan daya $169 \mathrm{~kW}$ atau $227 \mathrm{HP}$ dan berat $900 \mathrm{~kg}$.

4) Perhitungan Berat

Berat kapal terdiri dari dua komponen yaitu Lightweight (LWT) dan Deadweight (DWT). LWT merupaka berat kapal kosong yang terdiri dari berat baja, berat perlengkapan, dan berat permesinan kapal. Sedangkan DWT merupakan total dari berat muatan, kru dan barang bawaan, berat consumable dan berat roda. Berat LWT yang diperoleh dari perhitungan sebesar 11.706 ton. Sedangkan berat DWT yang diperoleh sebesar 6.158 ton.

5) Perhitungan Trim

Perhitungan trim mengacu pada SOLAS Chapter II-1, Part $B-1$, Regulasi 5-1. Berdasarkan regulasi ini, nilai trim maksimum kapal adalah $\pm 0.5 \%$ Lwl. Dengan kata lain, nilai trim maksimum kapal yang didesain adalah $0.051 \mathrm{~m}$. Dalam hal ini, hasil perhitungansebesar $0.011 \mathrm{~m}$ dan termasuk trim haluan. 6) Perhitungan Trim

Hasil analisis perhitungan sebagai berikut:

Tabel 3.

Hasil analisis stabilitas

\begin{tabular}{lcccccc}
\hline \hline \multirow{2}{*}{ Kriteria } & \multirow{2}{*}{ Batasan } & \multirow{2}{*}{ Satuan } & \multicolumn{5}{c}{ Kondisi Tangki } \\
\cline { 4 - 7 } & & & $100 \%$ & $75 \%$ & $50 \%$ & $10 \%$ \\
\hline $\begin{array}{l}\text { Luas gambar di } \\
\text { bawah kurva }\end{array}$ & & & & & & \\
$\begin{array}{l}\text { a. GZ } \theta_{\max }=30^{\circ} \\
\text { b. GZ } \theta_{\max }=4.87\end{array}$ & m.deg & 11.07 & 11.10 & 11.13 & 11.16 \\
$\begin{array}{l}30^{\circ}-40^{\circ} \\
\text { Lengan } \\
\text { pengembali GZ }\end{array}$ & $>1.72$ & m.deg & 5.917 & 5.873 & 5.829 & 5.722 \\
$=30^{\circ}$ & & $\mathrm{m}$ & 0.664 & 0.662 & 0.660 & 0.656 \\
$\begin{array}{l}\text { Lengan } \\
\text { pengembali }\end{array}$ & $>15.0$ & $\mathrm{deg}$ & 30 & 30 & 30 & 30 \\
$\begin{array}{l}\text { Ketinggian } \\
\text { metasenter }\end{array}$ & $>3.50$ & $\mathrm{~m}$ & 1.418 & 1.428 & 1.439 & 1.454 \\
$(\mathrm{GM})$ & & & $\mathrm{A}$ & $\mathrm{A}$ & $\mathrm{A}$ & $\mathrm{A}$ \\
\hline Kondisi & & & & & & \\
\hline \hline
\end{tabular}

Keterangan:

$\mathrm{A}=$ Accepted 


\section{7) Perhitungan Freeboard}

Perhitungan freeboard standar mengacu pada Peraturan Standar Kapal Non Konvensi Berbendera Indonesia. Dalam menghitung freeboard terdapat beberapa koreksi yang perlu dilakukan antara lain koreksi terhadap $\mathrm{Cb}$, koreksi terhadap tinggi kapal, dan koreksi terhadap bangunan atas. Harga freeboard kapal sebesar $1 \mathrm{~m}$ sedangkan harga freeboard minimum sebesar 0.35 . sehingga freeboard desain telah memenuhi peraturan.

\section{E. Gambar Rencana Garis dan Rencana Umum}

Rencana garis merupakan gambaran bentuk lambung kapal yang diproyeksikan menjadi tiga sudut pandang yaitu sudut pandang depan, samping, dan atas. Hasil desain rencana garis menggunakan bantuan AutoCad dapat dilihat pada Gambar 6

Setelah memperoleh desain rencana garis, dapat dibuat desain rencana umum sesuai fungsi dan peralatan kapal seperti pada Gambar 8.
SIDE VIEW

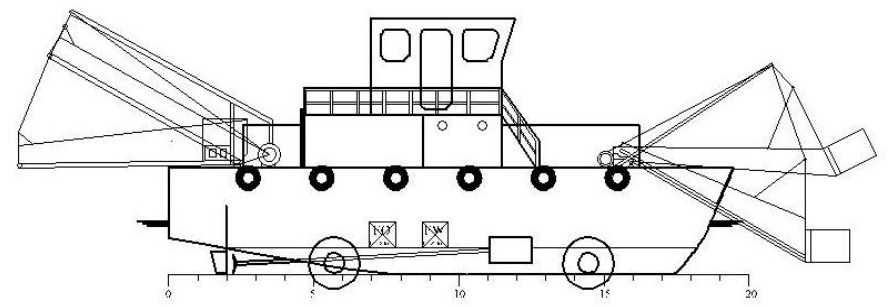

MAIN DECK

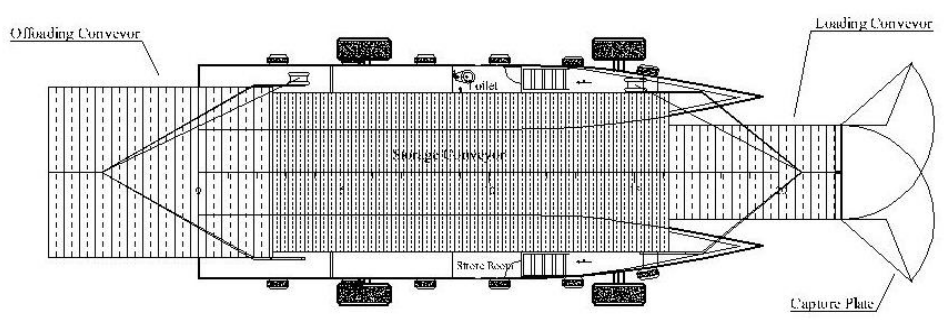

FRONT VIEW

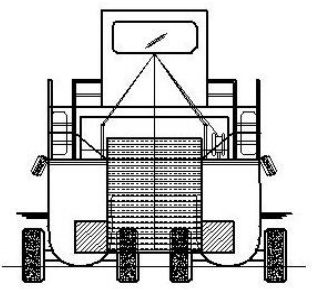

NAVIGATION DECK

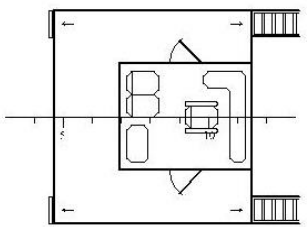

Gambar. 8. General Arrangement Trash Skimmer Amphibi-Boat

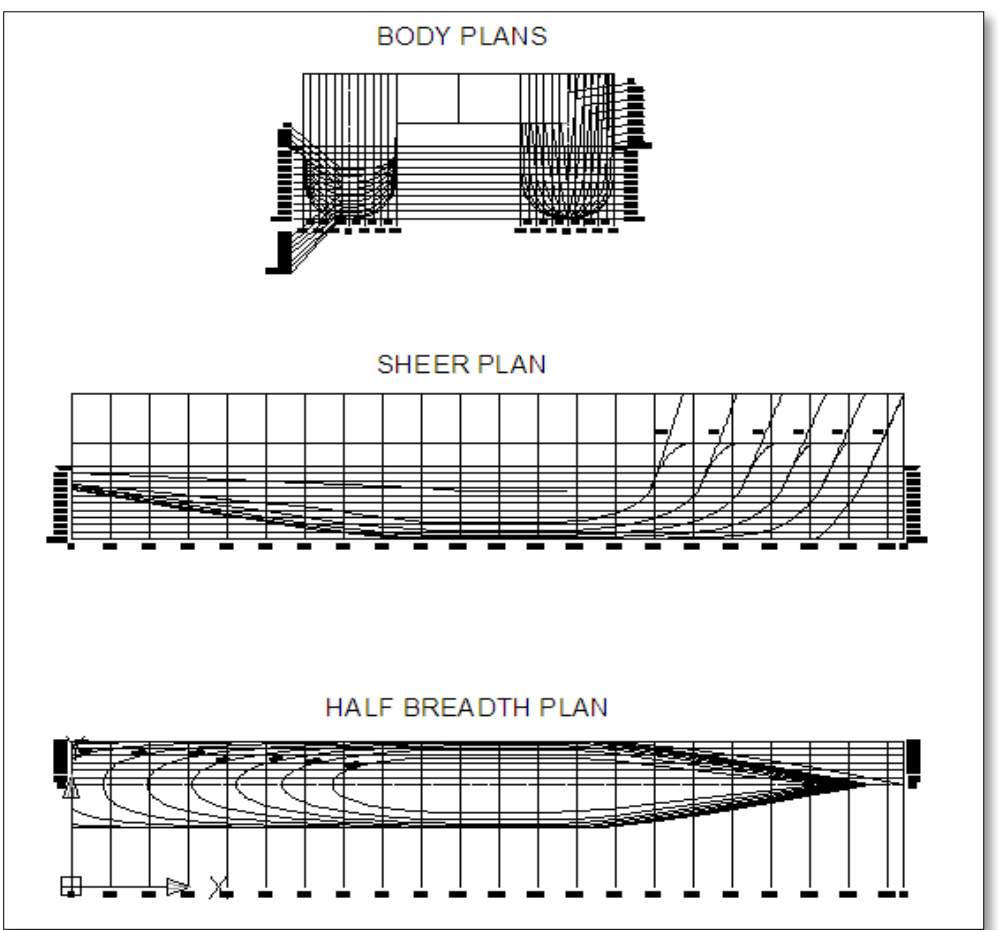

Gambar. 9. Lines Plan Trash Skimmer Amphibi-Boat 


\section{F. Sistem Amfibi}

Konsep amfibi yang diterapkan pada kapal memiliki pengaruh cukup penting pada elemen kapal sehingga pada proses desin perlu diperhatikan beberapa hal antara lain pemilihan mesin induk, pemasangan roda, dan sitem kerja Trash Skimmer Amphibi-Boat.

Secara garis besar sistem propulsi pada kendaraan ini menyerupai dengan sistem propulsi kendaraan darat (kendaraan yang dijadikan acuan adalah truk). Perbedaannya adalah adanya shaft (poros) tambahan yang dipasang di bagian belakang mesin yang berfungsi untuk menghubungkan mesin induk dengan propeller seperti pada Gambar 10.

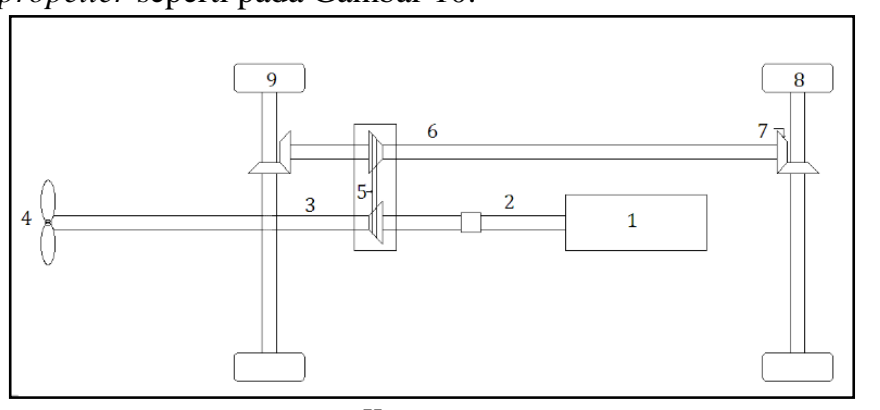

1. Mesin induk

2. Shaft utama

3. Shaft propeller

4. Propeller

5. Drive belt

Gambar. 10. Sistem Transmisi Kapal

Daya yang dikerluarkan mesin mengakibatkan shaft utama berputar. Shaft utama menghubungkan antara mesin induk dengan CTV input dan output. Pada ujung shaft utama terdapat bevel gear yang terhubung dengan drive belt dan shaft propeller. Drive belt sendiri bergungsi untuk menyalurkan daya yang berasal dari shaft utama ke shaft roda sehingga shaft roda dapat bergerak. Shaft utama yang terhubung langsung dengan shaft propeller mengakibatkan dapat bergeraknya shaft propeller.

Saat berada di sungai, daya yang berasal dari mesin induk mengakibatkan shaft utama berputar. Ketika shaft utama berputar, secara otomatis shaft propeller juga ikut berputar karena kedua shaft tersebut berhubungan langsung sehingga propeller dapat berputar. Di saat yang bersamaan drive belt tidak diaktifkan sehingga shaft roda tidak ikut berputar saat shaft utama berputar. Begitu pula sebaliknya saat kendaraan berada di darat.

\section{KESIMPULAN DAN SARAN}

\section{A. Kesimpulan}

Berdasarkan pembahasan yang telah diuraikan pada beberapa bab sebelumnya, dapat ditarik kesimpulan sebagai berikut:

1) Berdasarkan data jumlah sampah yang diperoleh dari Dinas Kebersihan Provinsi DKI Jakarta dapat ditentukan voleme sampah yang diangkut oleh kapal setiap beroperasi sebesar 5.5 ton.
2) Berdasarkan analisis teknis menggunakan metode kapal acuan diperoleh ukuran utama sebagai berikut:
a. Length Overall (LOA)
$: 10.7$ meter
b. Length of Peendicular (LPP) : 10.6 meter
c. Length of Waterline (LWL) $: 10.263$ meter
d. Breadth Moulded (BM) : 4 meter
e. Breadth of Demihull (B1) : 1.2 meter
f. $\quad \operatorname{Draught}(\mathrm{T})$
g. Depth (D)
h. Block Coefficient $(\mathrm{CB})$
$: 1$ meter
$: 2$ meter
$: 0.579$

3) Kapal ini dapat dioperasikan di sungai lain yaitu Sungai Sunter dan Sungai Banjir Kanal Timur.

\section{B. Saran}

Berdasarkan hasil analisis yang telah dilakukan pada Tugas Akhir ini terdapat beberapa saran yang mungkin dapat dilakukan sebagai analisis lanjutan antara lain sebagai berikut:

1) Perlu adanya perhitungan struktur lambung beserta kontruksinya.

2) Perlu adanya analisis yang lebih detail mengenai sistem amfibi kapal khususnya dalam sistem gerak kapal.

3) Perlu adanya perhitungan biaya produksi kapal

\section{DAFTAR PUSTAKA}

[1] "Wikipedia," 1 Desember 2015. [Online]. Available: https://id.wikipedia.org/wiki/Ci_Liwung. [Diakses 5 Januari 2016].

[2] A. G. Pramoko, "Studi Perancangan Trash-Skimmer Boat di Perairan Teluk Jakarta," Jurnal Tugas Akhir Jurusan Teknik Perkapalan FTK ITS, 2013.

[3] D. Watson, Practical Ship Design, vol. 1, R. Bhattacharyya, Penyunt., Oxford: Elsevier, 1998.

[4] W. Arianto, "Desain Kapal Wisata Katamaran Untuk Kepulauan Karimunjawa," Jurnal Tugas Akhir Jurusan Teknik Perkapalan FTK ITS, 2016. 